\title{
THE MEASUREMENT OF TESTOSTERONE AND OESTRADIOL-17 $\beta$ USING IODINATED TRACERS AND INCORPORATING AN AFFINITY CHROMATOGRAPHY EXTRACTION PROCEDURE
}

\author{
R. Webi, G. Baxter, D. McBride, G. D. Nordblom* and M. P. K. Shaw $†$ \\ AFRC, Animal Breeding Research Organisation, Dryden Laboratory, Roslin, Midlothian EH25 9PS, \\ U.K. and *Ligand Assay Laboratory, Department of Pathology, University of Michigan, Ann Arbor, \\ MI 48109, U.S.A.
}

(Received 25 May 1985)

\begin{abstract}
Summary - The development of sensitive radioimmunoassays (RIA) for testosterone and oestradiol-17\%, utilising ${ }^{125}$ I-radioligands, is described. Use of an homologous bridge at the same site of attachment, for both the radioligand and the steroid-carrier protein conjugate employed in raising antibodies, normally results in a loss of assay sensitivity and precision. This was overcome in the oestradiol assay by utilising an heterologous configuration at the site of attachment (11 $\alpha$ vs $11 \beta)$. In contrast, for testosterone, even though an homologous bridge and site of attachment was used for the radioligand and the steroid carrier protein conjugate, a very sensitive assay with extremely high antibody titres (dilution of $1: 2 \times 10^{6}$ ) was achieved. This finding was repeated with a different antiserum suggesting that the "bridge binding" phenomenon may be related to the position of attachment to the steroid molecule. In addition, an antibody-Sepharose 4B affinity chromatography extraction procedure has been developed for both oestradiol and testosterone. This approach allows the measurement of very low concentrations of steroids from large volumes of a variety of biological fluids. As antibody-linked Sepharose 4B uses high concentrations of antibody, steroids of similar structure are extracted from biological fluids. However, the cross-reactivity of these related steroids are very low in the RIA's, ensuring good specificity.
\end{abstract}

\section{INTRODUCTION}

Although a number of methods have been described for the measurement of sternid hormones [1] there is still a requirement for more precise and sensitive methods to assay these hormones in plasma or serum. This is especially relevant for the study of reproduction in domestic animals where the concentrations of oestradiol- $17 \beta$ and testosterone in the peripheral circulation are extremely low [see reviews 2-4].

An increase in RIA sensitivity has been achieved by using the higher specific activity $\gamma$-emitting radionuclides such as ${ }^{125} I$ as opposed to $\beta$-emitting radioisotopes. This approach also has the added advantage of the cost effective manner in which samples can be counted [5-8]. A serious disadvantage however, of using radioiodinated labels is the affinity that the antibody may show, not only for the hapten, but for the bridge through which it is attached to the carrier protein. As reviewed recently $[5,6]$ the "bridge-binding" phenomenon can be overcome by

Current addresses: *Dept. of Pharmacokinetics/Drug Metabolism, Warner-Lambert Co., Pharmaceutical Research Division, 2800 Plymouth Road, Ann Arbor, MI 48105, U.S.A.

†45 Murray Road, Northwood. Middlesex HA6 2YP, U.K. using either an homologous bridge to different configurations at the same site of attachment to the hapten [9] or by using an heterologous bridge $[7,10]$. The occurrence of "bridge binding" may also be affected by the position of attachment to the steroid, even when using an homologous bridge and site of attachment. The present paper describes our results using an homologous bridge, from different configurations at the same site of attachment, in the case of oestradiol, and an homologous bridge from the same site, in the case of testosterone.

Even with the utilisation of these techniques for the development of sensitive assays, relatively large volumes of plasma or serum are still required to measure very low concentrations of steroids in the peripheral circulation of domestic animals [11, 12]. Classical extraction procedures utilise a range of solvents normally followed by chromatographic purification to remove cross-reacting substances. The large volumes of fluid (at least $3 \mathrm{ml}$ ) that have to be extracted necessitate the use of large quantities of solvents which, as well as being hazardous, costly and laborious, increases the risk of high assay blank values [8] and low recoveries. In this report we also describe the use of an affinity chromatography extraction procedure [13] and its incorporation into very sensitive RIA's for the measurement of low concentrations of testosterone and oestradiol-17 $\beta$. 


\section{EXPERIMENTAL}

\section{Chemicals and glassware}

Testosterone-3-carboxymethyloxime (testosterone3-CMO) was purchased from Steraloids, Croydon, U.K., and 17 $\beta$-oestradiol-11 $\alpha$-hemisuccinate and $17 \beta$-oestradiol-11 $\beta$-hemisuccinate were supplied by Upjohn Co. (Kalamazoo, Michigan, U.S.A.). Pig skin gelatin, merthiolate (thimerosal), sodium metabisulphite, chloramine-T and steroids, used in the standard curves and cross-reactivity studies, were purchased from Sigma Chemical Co. (Poole, Dorset, U.K.). $\mathrm{Na}{ }^{125} \mathrm{I}$ (carrier free) and tritiated steroids $\left[1,2,6,7-{ }^{3} \mathrm{H}\right]$ testosterone $\quad(3.4 \mathrm{TBq} / \mathrm{mmol})$; $\left[2,4,6,7,16,17-{ }^{3} \mathrm{H}\right]$ oestradiol - $17 \beta \quad(5.4 \mathrm{TBq} / \mathrm{mmol})$; $\left[2,4,6,7-{ }^{3} \mathrm{H}\right]$ oestrone $(3.0 \mathrm{TBq} / \mathrm{mmol}) ;[1,2,6,7,16,17-$ $\left.{ }^{3} \mathrm{H}\right]$ progesterone $(3.9 \mathrm{TBq} / \mathrm{mmol})$ and $\left[1,2,6,7 \cdot{ }^{3} \mathrm{H}\right] \mathrm{an}-$ drostenedione $(3.0 \mathrm{TBq} / \mathrm{mmol})$ were obtained from Amersham International (Buckinghamshire, U.K.). All solvents (analar grade) and scintillation fluid, except for "aristar" ethanol (BDH Chemicals, Glasgow, U.K.) were purchased from Fisons Ltd. (Loughborough, U.K.). Sephadex G-25 (finemesh), LH20 and CNBr-activated Sepharose 4B were supplied by Pharmacia Fine Chemicals (Uppsala, Sweden).

Purity of the water and cleanliness of the glassware is of particular importance when measuring low steroid concentrations. Therefore the water was coarse filtered to remove particulate material, deionised and finally double glass distilled. The glassware, except the columns used for the affinity chromatography, was washed in a Meile dishwasher, rinsed twice in distilled water and finally baked at $200^{\circ} \mathrm{C}$ for $2 \mathrm{~h}$ in a laboratory oven.

After assessing a number of different columns for use in the affinity chromatography extraction procedure the most appropriate were those using $10 \mathrm{~mm}$ dia (porosity 1) glass sinter discs (Schott Glass, U.K.). The sinter discs were inserted into soda glass columns $10 \times 120 \mathrm{~mm}$ with $55 \mathrm{~mm}$ tapered outlets. This size of column allows a large number $(\geq 100)$ to be used simultaneously.

\section{Syntheses}

Syntheses of steroid conjugates were similar to those described by Nordblom et al.[7].

\section{Preparation of testosterone-3-CMO-histamine}

Testosterone-3-CMO $(0.0668 \mathrm{mmol})$ and triethylamine (Sigma, $0.133 \mathrm{mmol}$ ) were dissolved in freshly-distilled dioxane $(\mathrm{BDH}, 3 \mathrm{ml})$ and the reaction mixture was cooled to $10^{\circ} \mathrm{C}$. Isobutylchloroformate (Sigma, $0.0734 \mathrm{mmol}$ ) was added resulting in the immediate formation of a white precipitate; the reaction mixture was stirred for an additional $30 \mathrm{~min}$. Histamine (Sigma, $0.0668 \mathrm{mmol}$ ), dissolved in $2 \mathrm{ml}$ dioxane plus 3 drops of water, was added and the mixture was stirred overnight at $10^{\circ} \mathrm{C}$. The reaction mixture was poured into water $(40 \mathrm{ml})$ and the aqueous layer was extracted 6 times with $\mathrm{CH}_{2} \mathrm{Cl}_{2}(15 \mathrm{ml})$. The combined organic layer was dried with $\mathrm{Na}_{2} \mathrm{SO}_{4}$ and concentrated to approx $500 \mu \mathrm{l}$ in vacuo. The concentrate was loaded onto a $20 \times 20 \mathrm{~cm}$ silica gel preparative thin layer chromatography (TLC) plate $(60 \mathrm{~F} 254,0.25 \mathrm{~mm}$ thickness; Merck, Darmstadt, West Germany) and developed with $\mathrm{CH}_{2} \mathrm{Cl}_{2}-\mathrm{CH}_{3} \mathrm{OH}-\mathrm{NH}_{4} \mathrm{OH} \quad(90: 10: 1$ by vol). The plate was treated with fluorescent dye and visualised with a u.v. lamp showing three bands at $R_{\mathrm{f}}$ $0.26,0.10$ and at the origin. The unreacted testosterone-3-CMO remained at the origin. The bands at $R_{\mathrm{f}} 0.10$ (band $\mathrm{A}$ ) and 0.26 (band $\mathrm{B}$ ) were scraped off the plate and extracted with ethanol $(10 \mathrm{ml})$. The ethanol solutions were evaporated to dryness and the resulting materials radioiodinated as described below. Radioiodinated band $\mathrm{A}$ was bound by antibody to testosterone (as described in the Results section) and therefore proved to be the desired product.

\section{Preparation of $17 \beta$-oestradiol-Il $\alpha$-succinyl-tyro- sinemethylester}

$17 \beta$-Oestradiol-11 $\alpha$-hemisuccinate $\quad(0.030 \mathrm{mmol})$ and triethylamine $(0.060 \mathrm{mmol})$ were dissolved in freshly distilled dioxane $(5 \mathrm{ml})$ and the mixture was cooled to $10^{\circ} \mathrm{C}$. Isobutylchloroformate $(0.033 \mathrm{mmol})$ was added resulting in the immediate formation of a white precipitate. After the reaction had mixed for $30 \mathrm{~min}$ tyrosine methyl ester (TME, $0.030 \mathrm{mmol}$ ), dissolved in dioxane $(2 \mathrm{ml})$, was added and the reaction mixture was stirred overnight at $10^{\circ} \mathrm{C}$. The mixture was poured into water $(40 \mathrm{ml})$ and made slightly acidic ( $\mathrm{pH} 4.0)$ with dilute $\mathrm{HCl}$. The aqueous phase was extracted 6 times with $\mathrm{CH}_{2} \mathrm{Cl}_{2}(15 \mathrm{ml})$. The combined organic layer was dried with $\mathrm{Na}_{2} \mathrm{SO}_{4}$ and concentrated to about $500 \mu \mathrm{l}$ in vacuo. The concentrate was loaded onto a $20 \times 20 \mathrm{~cm}$ preparative TLC plate and developed with $\mathrm{CH}_{2} \mathrm{Cl}_{2}-\mathrm{CH}_{3} \mathrm{OH}-\mathrm{CH}_{3} \mathrm{COOH}$ (95:5:1, by vol). As in the case of the testosterone-3-CMO-histamine synthesis above, three bands were found. Unreacted $17 \beta$-oestradiol- $11 \alpha$-hemisuccinate remained at the origin. In addition, two bands were found at $R_{\mathrm{f}} 0.33$ (band A) and 0.63 (band B). The silica for each band was scraped from the plate and extracted with ethanol $(10 \mathrm{ml})$. When the material from band $A$ was radioiodinated as described below the label was bound by the oestradiol-17 $\beta$ antibody as described in the Results section.

\section{Preparation of $17 \beta$-oestradiol-11 $\beta$-succinyl-tyro- sinemethylester}

This was prepared as described for the $17 \beta$ ocstradiol-11 $\alpha$-TME except that $17 \beta$-oestradiol$11 \beta$-hemisuccinate was used. As for the $17 \beta$ oestradiol-11 $\alpha$-TME separation by TLC following synthesis gave three bands. Unreacted oestradiol$11 \beta$-hemisuccinate remained at the origin. In addition there were two bands at $R_{\mathrm{f}} 0.29$ (band A) 
and 0.57 (band B). Furthermore, as for the $17 \beta$-oestradiol-11 $\alpha$-TME, when band $\mathrm{A}$ was radioiodinated, see below, the label was bound by the ocstradiol antibody as described in the Results section.

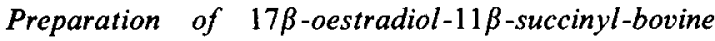 serum albumin}

$17 \beta$-Oestradiol- $11 \beta$ hemisuccinate $\quad(0.023 \mathrm{mmol})$ was dissolved in dimethyl formamide $(2 \mathrm{ml})$ and $\mathrm{H}_{2} \mathrm{O}$ (1 ml). 1-Ethyl-3-(3-dimethyl-aminopropyl)carbodiimide $(0.192 \mathrm{mmol})$ was added and the mixture stirred for $30 \mathrm{~min}$. Bovine serum albumin (36 mg), dissolved in sodium phosphate buffer $(0.02 \mathrm{M}, \mathrm{pH} 7.8,10 \mathrm{ml})$, was added dropwise to the steroid solution and stirred for 4 days at room temperature in the dark. The reaction mixture was dialysed against $0.05 \mathrm{M} \mathrm{NaHCO}_{3}(2 \times 500 \mathrm{ml})$ and $\mathrm{H}_{2} \mathrm{O}(2 \times 500 \mathrm{ml})$ and subsequently dried by lyophilization.

\section{Radioiodination}

Iodination of the testosterone-3-CMO-histamine, $17 \beta$-oestradiol-11 $\alpha$-TME and $17 \beta$-oestradiol-11 $\beta$ TME were carried out as described previously by Hunter et al. [14]. Aliquots of the steroid derivatives $(2 \mu \mathrm{g})$ were stored in $10 \mu \mathrm{l}$ ethanol (aristar) at $-50^{\circ} \mathrm{C}$. Prior to iodination the solvent was evaporated to dryness under $\mathrm{N}_{2}$ and the steroid conjugate was then reconstituted in $40 \mu \mathrm{l}$ phosphate buffer (0.5 M, pH 7.5).

Aqueous $\mathrm{Na}\left[{ }^{125} \mathrm{I}\right](37 \mathrm{MBq}, 10 \mu \mathrm{l})$ was added. The reaction was initiated by the addition of chloramine$\mathrm{T}(10 \mu \mathrm{g} / 10 \mu \mathrm{l}$ in $0.05 \mathrm{M}$ sodium phosphate buffer, $\mathrm{pH}$ 7.5). After mixing and incubation at ambient temperature for 2 min the reaction was quenched by the addition of sodium metabisulphite $(10 \mu \mathrm{g} / 10 \mu 1$ in $0.05 \mathrm{M}$ phosphate buffer, $\mathrm{pH} 7.5$ ).

In the case of the oestradiol-17 $\beta$ derivatives the reaction mixture was transferred to a $10 \times 200 \mathrm{~mm}$ Sephadex G25 (fine mesh) column, previously swollen in $0.05 \mathrm{M}$ phosphate buffer $(\mathrm{pH} 7.5)$. The iodinated steroid was eluted under pressure using a peristaltic pump, with $0.05 \mathrm{M}$ sodium phosphate buffer $(\mathrm{pH} \mathrm{10.5)}$. Approximately $1 \mathrm{ml}$ aliquots were collected directly into glass tubes containing $200 \mu \mathrm{l}$ phosphate buffer $(0.5 \mathrm{M}, \mathrm{pH} 7.5)$. The first peak eluted was discarded and the second peak, normally fractions 20-30, were pooled and adjusted to $\mathrm{pH} 7.5$ and stored at $4^{\circ} \mathrm{C}$. The specific activity of the label was assessed as described previously [5, 7] and was found to be approx $48 \mathrm{TBq} / \mathrm{mmol}$. The shelf-life of the material was at least 60 days.

In the case of the testosterone derivative, following iodination, the reaction volume was increased to $500 \mu 1$ by addition of phosphate buffer $(0.05 \mathrm{M}$, pH 7.5) and then transferred to a tapered glass stoppered centrifuge tube. The iodinated derivative was extracted by mixing for 1 min with $500 \mu 1$ ethyl acetate. The solvent phase was transferred to a second glass vial and the reaction mixture extracted for a second time. The combined solvent was then evaporated to a vol of $200 \mu 1$, by incubating in a water bath at $40^{\circ} \mathrm{C}$, under a stream of air. The concentrated preparation was then loaded onto a plastic backed silica gel TLC plate $(20 \times 20 \mathrm{~cm})$ as a continuous streak. The plate was developed in $\mathrm{CH}_{2} \mathrm{CL}_{2}-\mathrm{CH}_{3} \mathrm{OH}-\mathrm{CH}_{3} \mathrm{COOH}$ (90:10:1, by vol) for approx $2 \mathrm{~h}$. The plate was scanned, using a minimonitor and the required band $\left(R_{\mathrm{f}} 0.8\right)$ was cut out and the iodinated steroid eluted by incubating overnight in ethanol (aristar) at $4^{\circ} \mathrm{C}$. Two other bands at the origin and just behind the solvent front were discarded. The ethanol was filtered through a Pasteur pipette containing glass wool to remove particulate silica gel. The material was stored at $4^{\circ} \mathrm{C}$ until use, the shelf life of the label being usually at least 90 days. The specific activity of the label was found to be approx $63 \mathrm{TBq} / \mathrm{mmol}$.

Recently one of the authors (G. D. Nordblom, pers. commun.) has developed an HPLC procedure for purifying the radiolabelled testosterone and oestradiol-1 $1 \alpha$-TME derivatives. Puritication was performed on an Altech 600 RPA $C_{18}$ reverse phase column. The entire radioiodination reaction mixture was injected on the column using a Rheodyne injector fitted with a $100 \mu 1$ loop. A Spectra-Physics 8700 pump and solvent delivery system provided the following mobile phase at a flow rate of $1 \mathrm{ml}$ per min: for oestradiol-17 $; 0-5 \mathrm{~min}$, an isocratic mixture of $20 \% \mathrm{CH}_{3} \mathrm{CN}$ (A), $80 \% 0.05 \mathrm{M}$ potassium formate buffer, $\mathrm{pH} 4.0$ (B), 5-55 min, a $20-45 \%$ gradient of $\mathrm{A}$; 55-80 min, a $45-70 \%$ gradient of A; for testosterone; $0.5 \mathrm{~min}$ an isocratic mixture of $20 \% \mathrm{~A}$ and $80 \% \mathrm{~B}$, 5-80 min, a $20-60 \%$ gradient of $A$.

The clution pattern of the ocstradiol-17 $\beta$ label consisted of free iodine at $3 \mathrm{~min}$, monoiodinated TME at $52 \mathrm{~min}$ and diiodinated TME at $54 \mathrm{~min}$. Several other peaks at $61,64,69$ and $74 \mathrm{~min}$ were also eluted. The material in these peaks was not bound by antibody to oestradiol and undoubtedly correspond to derivatives that are iodinated on the A-ring of the steroid. The elution pattern of the testosterone label consisted of free iodide at $3 \mathrm{~min}$ and peaks at 56 , 59 and $65 \mathrm{~min}$ all three of which were bound by antibody to testosterone and are probably due to 2-iodo, 5-iodo and 2,5-diiodo derivatives of the imidazole ring of the histamine functional group.

\section{Antisera}

The testosterone antisera used in the RIA and also the oestradiol and testosterone antisera used for linking to the CNBr-activated Sepharose 4B were raised in sheep as described previously [16]. The oestradiol-17 $\beta$ antisera used in the radioimmunoassay was raised in rabbits against $17 \beta$-oestradiol-11 $\beta$-succinyl-bovine serum albumin (BSA) in collaboration with H. M. Fraser and A. McNeilly (MRC, Reproductive Biology Unit, Edinburgh). Rabbits were injected intra-dermally 
with $150 \mu \mathrm{g} 17 \beta$-oestradiol-11 $\beta$-succinyl-BSA in a $2 \mathrm{ml}$ emulsion of saline: Freunds complete adjuvant (ratio 2:3). The animals were then boosted at approx 3 month intervals with $50-100 \mu \mathrm{g}$ of oestradiol conjugate in a $2 \mathrm{ml}$ emulsion of saline: Freunds incomplete adjuvant (ratio 2:3). Animals were bled at weekly intervals following boosting and the different pools of serum characterised. The anti-oestradiol $17 \beta$ serum used from rabbit 32 (Table 1) was collected following the first booster injection and anti-oestradiol-17 $\beta$ serum from rabbit 48 (Table 1) was collected following the second booster injection. Specificity of the antisera used in the radioimmunoassays was estimated by measuring $50 \%$ displacement of the label by the other steroids $[17,18]$.

Ovine oestradiol-17 $\beta$ and testosterone antisera were covalently coupled to $\mathrm{CNBr}$-activated Sepharose $4 \mathrm{~B}$ using the methodology recommended by the manufacturer. Briefly $9 \mathrm{~g}$ (dry weight) of Sepharose, swollen to give approx $35 \mathrm{ml}$ slurry, was placed on a grade 3 sintered glass filter funnel and washed with $1800 \mathrm{ml}$ of $1 \mathrm{mM} \mathrm{HCl}$. The slurry was then transferred to a $50 \mathrm{ml}$ ground glass stoppered test-tube containing $150 \mu \mathrm{l}$ of antiserum, in $18 \mathrm{ml}$ of coupling buffer $\left(\mathrm{NaHCO}_{3}, 0.1 \mathrm{M} ; \mathrm{NaCl}, 0.5 \mathrm{M} ; \mathrm{pH} 8.3\right)$. The solution was mixed overnight at $4^{\circ} \mathrm{C}$ on an end over end mixer. Unbound material was removed by washing with $50 \mathrm{ml}$ coupling buffer on the sintered glass filter funnel. Remaining residual active groups on the Sepharose were blocked by incubating with $200 \mathrm{ml}$ ethanolamine ( $1 \mathrm{M}, \mathrm{pH} 9.0)$ for $2 \mathrm{~h}$ at ambient temperature. Non-covalently bound material was removed by four alternate washes with high (borate buffer, $0.1 \mathrm{M}, \mathrm{pH} 8.0$ ) and low (acetate buffer, $0.1 \mathrm{M}$ pH 4.0 , containing $0.5 \mathrm{M} \mathrm{NaCl}) \mathrm{pH}$ buffers. Finally the antibody bound Sepharose was washed, resuspended and stored at $4^{\circ} \mathrm{C}$ in $75 \mathrm{ml}$ phosphate buffered saline $(0.05 \mathrm{M}$, pH $7.5,0.01 \%$ thimerosal) ready for use.

\section{Affinity chromatography extraction procedure}

Approximately $1,000 \mathrm{cpm}$ of the appropriate tritiated steroid $(10 \mu \mathrm{l}$ diluted in ethanol) together with the appropriate sample $(5-3,000 \mu 1)$ were pipetted into screw-capped glass culture tubes $(16 \times 125 \mathrm{~mm})$, mixed and incubated for $30 \mathrm{~min}$ at room temperature. A further $10 \mathrm{ml}$ of double distilled $\mathrm{H}_{2} \mathrm{O}$ was then added to each tube, followed by $500 \mu 1$ of antibodySepharose. It was later found that as little as $50 \mu 1$ of antibody-Sepharose could be used therefore negating the need for recycling. The samples were then mixed end over end, for at least $2 \mathrm{~h}$ at room temperature or overnight at $4^{\circ} \mathrm{C}$. The contents of each tube were poured directly on to prewashed sintered glass columns and the aqueous waste discarded. The antibody-Sepharose residues in the tubes were then rinsed with $7 \mathrm{ml} \mathrm{H}_{2} \mathrm{O}$ and again poured on to the respective columns. The antibody-Sepharose in each column was washed with $20 \mathrm{ml} \mathrm{H}_{2} \mathrm{O}$ and the eluates allowed to run to waste. Residual water in the system was then removed by applying slight positive pressure using an aquarium pump. Bound hormone was then eluted with $3 \mathrm{ml} \mathrm{CH} 3 \mathrm{OH}-\mathrm{H}_{2} \mathrm{O}(90: 10, \mathrm{v} / \mathrm{v})$. Positive pressure was applied to ensure maximum elution of the solvent into glass test tubes $(125 \times 16 \mathrm{~mm})$. The eluate was evaporated to dryness in a Buchler Vortex evaporator at $40^{\circ} \mathrm{C}$ (Gallenkamp). The hormone extracts were reconstituted in $1800 \mu 1$ phosphate buffered saline, containing $0.1 \%$ gelatin (PBS-Gel), and then mixed for at least $20 \mathrm{~min}$ on a Vortex evaporator $\left(37^{\circ} \mathrm{C}\right)$. Recovery was assessed as a percentage of total counts by taking a $500 \mu 1$ aliquot of the reconstituted material and counting on a liquid scintillation counter (LKB, Rackbeta 1211). For example mean recovery for testosterone was $81.4 \%(c . v .=4.0 \%, n=160)$ and for oestradiol $-17 \beta 76.9 \%$ (c.v. $=6.0 \%, n=154)$ over several assays.

Two $500 \mu 1$ aliquots of the extracted and reconstituted steroid were then removed for radioimimunoassay. As the tritiated label used for recovery estimates does not interfere with gamma counts, individual recovery estimates were routinely made. However, because of the sensitivity of the assays (see Results section) correction was made for the weight of steroid added in the recovery counts.

After use the residual antibody-Sepharose was resuspended in $7 \mathrm{ml} \mathrm{H}_{2} \mathrm{O}$ and the slurry from each column pooled in a large sintered glass funnel (porosity 3) and recycled by 3 alternate washes in $\mathrm{CH}_{3} \mathrm{OH}$ and $\mathrm{H}_{2} \mathrm{O}$. The material was found to be very stable and was recycled, without loss of binding activity, at least 50 times over a 2 year period. However, it has been estimated that a $15 \mathrm{~g}$ batch of Sepharose provides enough material to extract over 2000 samples ( $50 \mu 1$ antibody-Sepharose) thereby reducing the need to recycle the material.

Some of the validation experiments (see Results section) also employed a solvent extraction procedure. In these cases the samples, which had previously been equilibrated with recovery label, were extracted with either $15 \mathrm{ml}$ (oestradiol-17 $\beta$ ) or $3 \mathrm{ml}$ (testosterone) diethyl ether by mixing for $15 \mathrm{~min}$ on a multivortexer (SMI). The aqueous phase was frozen in a dry ice-methanol bath and the solvent phase decanted into glass tubes $(125 \times 16 \mathrm{~mm})$ and evaporated to dryness in a Buchler vortex evaporator. The sample was then reconstituted in either assay buffer or $\mathrm{H}_{2} \mathrm{O}$ prior to assay or affinity chromatography extraction respectively.

\section{Radioimmunoassay}

The steroid standards $(500 \mathrm{pg} / \mathrm{ml})$ or unknown samples were dissolved in assay buffer (PBS-gel) and dispensed in duplicate or triplicate and made up to a constant volume of $500 \mu 1$ in assay buffer. A $100 \mu 1$ aliquot of iodinated steroid (approx 20,000 counts per $100 \mathrm{~s}$ ) was then added immediately followed by a $200 \mu 1$ aliquot of first antibody at an appropriate dilution (see Table 1). The assay was then incubated 
Table 1. Comparison of antisera and radioligands

\begin{tabular}{|c|c|c|c|c|c|c|}
\hline Antiserum & Immunogen & $\begin{array}{l}\text { Iodine labelled } \\
\text { conjugate }\end{array}$ & $\begin{array}{c}\text { Final } \\
\text { antibody } \\
\text { Titre }\left(\times 10^{-3}\right)\end{array}$ & $\begin{array}{c}\text { Percent of } \\
\text { label bound } \\
(\%)\end{array}$ & $\begin{array}{c}\text { Slope of } \\
\text { inhibition } \\
\text { curve }\end{array}$ & $\begin{array}{c}\text { Mass of steroid for } \\
50 \% \text { displacement } \\
\text { of bound label } \\
\text { (pg/tube) }\end{array}$ \\
\hline Sheep 501 & oestradiol-6-CMO* & $17 \beta$-oestradiol- $11 \alpha-\mathrm{TME}$ & $1: 120$ & 49 & $\dagger$ & 200 \\
\hline Sheep 614 & oestradiol-3-CME & $17 \beta$-oestradiol- $11 \alpha$-TME & $1: 28$ & 37 & $t$ & 400 \\
\hline Rabbit 32 & oestradiol-11 $\beta-\mathrm{H} \S$ & $17 \beta$-oestradiol-11 $\alpha-\mathrm{TME}$ & $1: 200$ & 40 & $-0.82^{w}$ & 20 \\
\hline Rabbit 48 & oestradiol-11 $\beta-\mathrm{H}$ & $17 \beta$-oestradiol- $11 \alpha-\mathrm{TME}$ & $1: 160$ & 38 & $-1.09^{y}$ & 5 \\
\hline Rabbit 32 & oestradiol- $11 \beta-\mathrm{H}$ & $17 \beta$-oestradiol- $11 \beta$-TME & $1: 200$ & 38 & $-0.60^{x}$ & 125 \\
\hline Rabbit 48 & oestradiol-11 $\beta-\mathrm{H}$ & $17 \beta$-oestradiol- $11 \beta$-TME & $1: 160$ & 62 & $-0.73^{z}$ & 96 \\
\hline Sheep 505 & testosterone-3-CMO & testosterone-3-CMO-histamine & $1: 2800$ & 82 & -0.99 & 40 \\
\hline Sheep 506 & testosterone-3-CMO & testosterone-3-CMO-histamine & $1: 2800$ & 84 & -1.2 & 28 \\
\hline
\end{tabular}

*Carboxymethyloxime; +Binding was inhibited over a very small range (see text for details); †Carboxymethyl ether; §Hemisuccinate. w versus $x$ and $y$ versus $z$ are significantly different $(P<0.001)$

at room temperature for approx $2 \mathrm{~h}$ followed by the addition of previously optimised precipitating reagents. These included $100 \mu 1$ normal sheep or rabbit serum, depending on first antibody, and $100 \mu \mathrm{l}$ of second antibody (raised in donkeys to either sheep or rabbit IgG) diluted in PBS gel, containing $0.1 \mathrm{M}$ EDTA. Following an overnight incubation at $4^{\circ} \mathrm{C}, 2 \mathrm{ml}$ of ice-cold PBS gel was added and the tubes centrifuged at $800 \mathrm{~g}$ for $30 \mathrm{~min}\left(4^{\circ} \mathrm{C}\right)$. The supernatants were immediately decanted to waste, tubes drained for $15 \mathrm{~min}$ and the radioactivity in the precipitates counted on a gamma counter LKB $(80,000$ Series Wallac or LKB 1271 Riagamma).

\section{Analysis of results}

The assay results were computed by the ABRO RIA program package based on the method of Rodbard and Lewald [19]. Scatchard analysis [20] of results was carried out by the RIA programme package, but were also re-calculated following correction for non-specific binding $[21,22]$. Significance of differences between the slopes of the standard curves and Scatchard plots were calculated by comparing the regression lines of the curves (Students $t$-test).

\section{RESULTS}

\section{Antibody characteristics}

Titres. The antibody titres and the various iodinated labels used are shown in Table 1. The most sensitive oestradiol assays were developed by using an heterologous configuration assay system consisting of $17 \beta$-oestradiol-11 $\alpha$-TME label with an antibody raised against $17 \beta$-oestradiol-11 $\beta$-BSA. For both of the oestradiol antisera tested the use of an $17 \beta$-oestradiol-11 $\beta$-TME label shifted the slope to the right, i.e. the weight of hormone required to inhibit binding was markedly increased. Also the slope of the standard curve was significantly shallower than the ideal -1.00 , as would be expected from classical "bridge binding" theory $[5,6]$.

Although 5 antisera, raised against oestradiol-17 $\beta$ conjugated at the three or six positions, were tested for their ability to bind to iodinated oestradiol-17 $\beta$ (17 $\beta$-oestradiol-11 $\alpha$-TME) only two antisera, sheep 501 and 614 (Table 1), were capable of binding the label. Binding of the iodinated label by these two antisera could be inhibited with unlabelled oestradiol. However, inhibition did not occur until at least $50 \mathrm{pg}$ of oestradiol had been added and then occurred over a narrow range (sheep 501: between $50-100$ pg; sheep 614: between $100-500 \mathrm{pg}$ ), thereby producing abnormal standard curves.

For the testosterone assay an homologous assay system (same chemical bridge and site of attachment) was used. Although extremely high titres were achieved (Tables 1 and 2), suggesting a "bridge binding" phenomenon, the label was capable of being displaced with unlabelled hormone (Table 2). Therefore at extremely high antibody dilutions very sensitive assays were obtained with both antisera.

From these initial studies rabbit 48 for the oestradiol-17 $\beta$ assay (using $17 \beta$-ocstradiol- $11 \alpha$-TME label), and sheep 505, for the testosterone assay (using testosterone-3-CMO-histamine label), were characterised further and then incorporated with an affinity chromatography extraction procedure.

Table 2. Binding characteristics of testosterone antiserum (sheep 505) at three dilutions

\begin{tabular}{lllcc}
\hline $\begin{array}{c}\text { Final } \\
\text { titre } \\
\left(\times 10^{-3}\right)\end{array}$ & $\begin{array}{c}\text { Slope of the } \\
\text { inhibition } \\
\text { curve }\end{array}$ & $\begin{array}{c}\text { Dissociation } \\
\text { constant (M) }\end{array}$ & $\begin{array}{c}\text { Percentage of } \\
\text { total label } \\
\text { bound (\%) }\end{array}$ & $\begin{array}{c}\text { Mass of } \\
\text { steroid for } 50 \% \\
\text { displacement } \\
\text { of bound label } \\
\text { (pg) }\end{array}$ \\
\hline $1: 2,800^{*}$ & -1.25 & (a) $1.9 \times 10^{-11} \mathrm{a}$ & 82 & 37 \\
$1: 10,000$ & -0.93 & (b) $1.1 \times 10^{-10} \mathrm{~b}$ & & 10 \\
$1: 20,000$ & -1.15 & $1.2 \times 10^{-11}$ & 55 & 5 \\
\hline
\end{tabular}




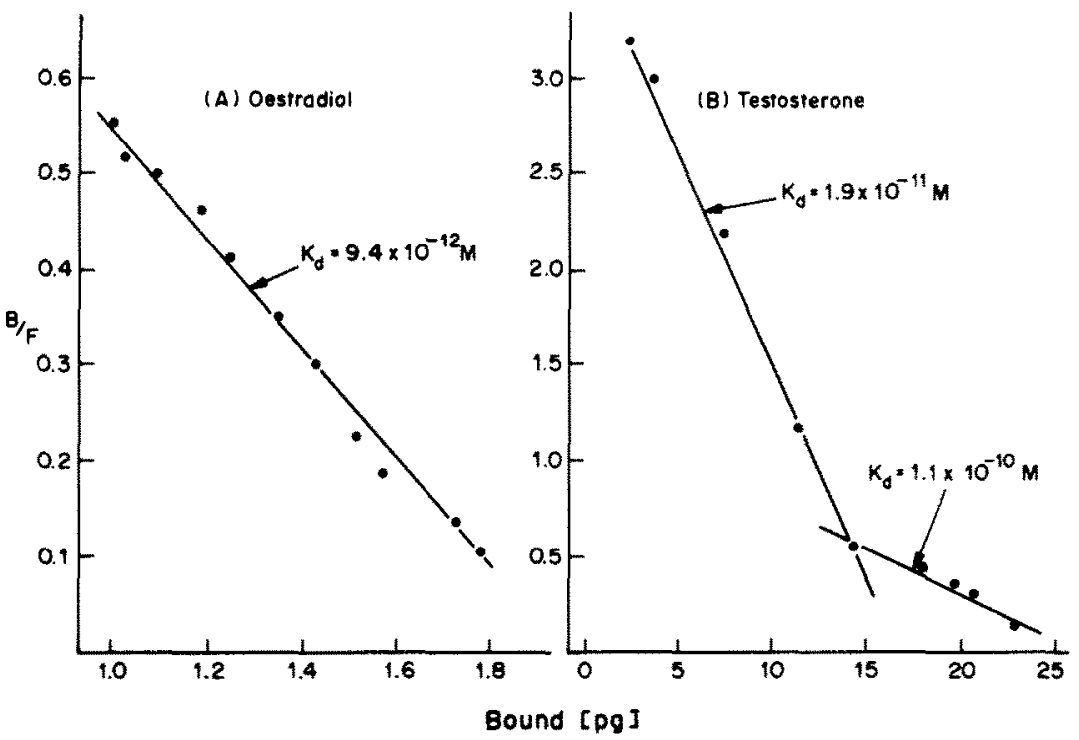

Fig. 1. Scatchard analyses of (A) oestradiol antiserum (rabbit 48) tested at a final dilution of 1:200,000 and (B) testosterone antiserum (sheep 505) tested at a final dilution of $1: 2,800,000$.

Antibody affinities. Scatchard analysis of the oestradiol-17 $\beta$ inhibition curve (rabbit 48 ) demonstrated that at the antibody dilution used there appeared to be only one population of binding sites with a dissociation constant $\left(K_{\mathrm{d}}\right)$ of $9.4 \times 10^{-12} \mathrm{M}$ (Fig. 1). When the testosterone antiserum (sheep 505) was tested at a lower antibody dilution (final dilution of $\left.1: 2.8 \times 10^{6}\right)$ two populations of antibodies were found (Fig. 1) which produced significantly different $(P<0.001)$ slopes (Table 2). However, when tested at two higher dilutions (Table 2) only the high affinity antibodies were detected. However, the slope of the inhibition curves were similar when the antiserum was tested at three dilutions. Both the oestradiol-17 $\beta$ (rabbit 48) and testosterone assays [sheep 505] (Fig. 1) were very sensitive when used at the higher dilutions, giving a minimum detectable dose of approx $800 \mathrm{fg}$ per tube. As the testosterone antibody was still binding $50 \%$ of the label this assay could probably be made even more sensitive by diluting the antiserum further.

Antibody specificity. All 3 antisera demonstrated good specificity (Table 3). Antiserum from rabbit 48 had a $16 \%$ cross-reactivity with oestrone, but England et al.[9] have previously demonstrated that very specific antisera can be obtained when oestradiol-17 $\beta$ is conjugated to the carrier proteins through the $11 \beta$ position. This is supported by the results using antiserum from rabbit 32 which showed only a $2 \%$ cross-reaction with oestrone. Antiserum from sheep 505 also showed good specificity, with only a $12 \%$ cross-reaction with $5 \alpha$-dihydrotestosterone.

\section{Affinity chromatography}

Extraction specificity. The specificity of the antibody-Sepharose was assessed by incubating with various tritiated steroids (Table 4). The results demonstrate that the method does provide some specificity, with progesterone showing very low crossreaction for both the testosterone and oestradiol linked antibodies. However, because of the high antibody concentrations, more closely related steroids were bound by both the testosterone and oestradiol antibody-Sepharose. The results also demonstrate that 2 or 3 washes with water, of the antibody-Sepharose, removed virtually all of the unbound steroid. A $3 \mathrm{ml}$ wash with $90 \%$ methanol was also very efficient at removing the antibody bound steroid. The results indicate that residual steroid contamination is negligible, therefore allowing re-use of the antibody-Sepharose if required [13].

Comparison of extraction procedures. Several methods of extraction of both testosterone (Table 5) and oestradiol (Table 6) were compared. Affinity chro-

Table 3. Antisera specificity showing percentage cross-reactivities

\begin{tabular}{|c|c|c|c|}
\hline \multirow[b]{2}{*}{ Steroid tested } & \multicolumn{2}{|c|}{$\begin{array}{l}\text { Oestradiol-17 } \beta \\
\text { antiserum }\end{array}$} & \multirow{2}{*}{$\begin{array}{c}\text { Testosterone } \\
\text { antiserum } \\
\text { Sheep } \\
505\end{array}$} \\
\hline & $\begin{array}{c}\text { Rabbit } \\
32\end{array}$ & $\begin{array}{c}\text { Rabbit } \\
48\end{array}$ & \\
\hline Oestradiol $17 \beta$ & 100 & 100 & 0.01 \\
\hline Oestrone & 3.2 & 16 & 0.01 \\
\hline Oestriol & 1.6 & 3.0 & 0.01 \\
\hline Testosterone & 3.2 & 1.2 & 100 \\
\hline Sa-Dihydrotestosterone & 0.3 & 0.1 & 12.1 \\
\hline Androsterone & 0.1 & 0.01 & 3.3 \\
\hline Androstenedione & 0.1 & 0.1 & 0.9 \\
\hline 5-Androsten-3 $3 \beta$-ol-17-one & - & - & 0.6 \\
\hline Progesterone & 0.8 & 0.01 & 0.01 \\
\hline
\end{tabular}

Antisera 32 and 48 were tested using the heterologous system (oestradiol-11x tyrosine methyl ester label) at final dilutions of $1: 200,000$ and $1: 160,000$ respectively. Sheep 505 was tested at a final antibody dilution of $1: 2.8 \times 10^{6}$. The following steroids also had $<1.0 \%$ cross reaction with all three antisera: 5 -androstan-3 $3,17 \beta$-diol; cortisol, corticosterone, etiocholan- $3 \alpha$. ol-17-one; 5-pregnen-16 $\alpha$-ol-3,20-dione; 4-pregnen-17 $\alpha$-ol-3,20 dione; 4-pregnen-20x-ol-3-one; 4-pregen-16 $\alpha-0$-3,20 dione. 
Table 4. Percentage recovery of various tritiated steroids following extraction with either oestradiol antibodies or testosterone antibodies linked to Sepharose 4B

\begin{tabular}{|c|c|c|c|c|c|c|c|c|}
\hline \multirow[b]{2}{*}{ Antiserum } & \multirow[b]{2}{*}{$\begin{array}{l}\text { Tritiated } \\
\text { steroid }\end{array}$} & \multicolumn{4}{|c|}{ Non-specifically bound hormone } & \multicolumn{3}{|c|}{ Bound hormone } \\
\hline & & Eluate & $\begin{array}{c}\text { First } \mathrm{H}_{2} \mathrm{O} \\
\text { wash }\end{array}$ & $\begin{array}{c}\text { Second } \\
\mathrm{H}_{2} \mathrm{O} \text { wash }\end{array}$ & $\begin{array}{l}\text { Total free } \\
\text { hormone } \\
\text { recovered }\end{array}$ & $\begin{array}{c}\text { First } \\
\text { methanol } \\
\text { wash }\end{array}$ & $\begin{array}{c}\text { Second } \\
\text { methanol } \\
\text { wash }\end{array}$ & $\begin{array}{c}\text { Total } \\
\text { steroid } \\
\text { recovered }\end{array}$ \\
\hline Oestradiol-17 $\beta$ & Oestradiol-17 $\beta$ & 3.7 & 0.9 & 0.6 & 5.2 & 83.5 & 1.5 & 90.2 \\
\hline Oestradiol- $17 \beta$ & Oestrone & 13.8 & 1.5 & 0.7 & 16.0 & 87.1 & 0.6 & 103.7 \\
\hline Oestradiol-17 $\beta$ & Progesterone & 82 & 11.0 & 3.0 & 96 & 2.0 & 0.0 & 98.0 \\
\hline Oestradiol-17 $\beta$ & Testosterone & 26.3 & 9.8 & 7.2 & 43.3 & 53.2 & 0.3 & 96.5 \\
\hline Oestradiol-17 $\beta$ & Androstenedione & 75.7 & 13.6 & 4.2 & 93.5 & 6.6 & 0.1 & 100.2 \\
\hline Testosterone & Oestradiol-17 $\beta$ & 16.9 & 4.3 & 2.9 & 24.1 & 65.3 & 3.5 & 92.9 \\
\hline Testosterone & Oestrone & 75.4 & 5.2 & 3.5 & 84.1 & 16.9 & 0.1 & 101.1 \\
\hline Testosterone & Progesterone & 69.7 & 16.4 & 6.1 & 92.2 & 5.7 & 0.1 & 98.0 \\
\hline Testosterone & Testosterone & 11.4 & 1.1 & 0.4 & 12.9 & 76.8 & 1.9 & 91.6 \\
\hline Testosterone & Androstenedione & 15.5 & 1.7 & 1.1 & 18.3 & 72.6 & 1.8 & 92.7 \\
\hline
\end{tabular}

Table 5. Comparison of three methods of extraction of testosterone from ovine follicular fluid

\begin{tabular}{lccc}
\hline \multicolumn{1}{c}{ Method of extraction } & $\begin{array}{c}\text { Mean percentage } \\
\text { recovery }( \pm \text { SEM) }\end{array}$ & $\begin{array}{c}\text { Inhibition } \\
\text { slope of } \\
\text { sample }\end{array}$ & $\begin{array}{c}\text { Mean testosterone } \\
\text { concentrations } \\
(\mathrm{ng} / \mathrm{ml} \pm \text { SEM })\end{array}$ \\
\hline Solvent followed by & & & \\
affinity chromatography & $79.6 \pm 1.3$ & -0.98 & $33.3 \pm 2.9$ \\
Solvent only & $90.2 \pm 2.3$ & -0.97 & $31.9 \pm 2.4$ \\
Affinity chromatography only & $92.5 \pm 1.0$ & -0.95 & $30.6 \pm 3.0$ \\
\hline
\end{tabular}

Each sample was assayed at 4 vol in quadruplicate, using sheep 505 antiserum, with duplicate recovery estimates at each level. The $50 \%$ inhibition point and slope of the inhibition curve was $40 \mathrm{pg} /$ tube and -0.91 respectively. All samples were parallel to the standard curve.

matography gave satisfactory results, since there was no significant differences in mean hormone concentrations between the various extractions methods and the samples were parallel to the inhibition curve. Moreover, the results were in agreement with follicular fluid oestradiol-17 $\beta$ concentrations measured without previous extraction [23]. Use of affinity chromatography to extract known amounts of oestradiol$17 \beta$, from various volumes of ovine serum, gave good recoveries (Table 7). As a further assessment of the effect of different sample volumes the recovery of exogenous oestradiol and testosterone, added to ovine serum, was measured. For oestradiol, $100 \mathrm{pg} / \mathrm{ml}$ added to ovariectomised ewe plasma was assayed at $4 \mathrm{vol},(150,250,500$ and $1000 \mu 1)$ in duplicate. Mean concentrations of oestradiol recovered were 99.7 , $111.9,98.9$ and $102.2 \mathrm{pg} / \mathrm{ml}$ respectively. The sample

Table 6. Comparison of different extraction procedures of oestradiol-17 $\beta$ from ovine follicular fluid

\begin{tabular}{lccc}
\hline \multicolumn{1}{c}{$\begin{array}{c}\text { Method of } \\
\text { extraction }\end{array}$} & $\begin{array}{c}\text { Mean percentage } \\
\text { recovery }( \pm \text { SEM) }\end{array}$ & $\begin{array}{c}\text { Inhibition } \\
\text { slope of } \\
\text { sample }\end{array}$ & $\begin{array}{c}\text { Mean oestradiol } \\
\text { concentrations } \\
\text { (ng/ml } \pm \text { SEM) }\end{array}$ \\
\hline $\begin{array}{l}\text { Solvent followed } \\
\text { by affinity } \\
\text { chromatography }\end{array}$ & $63.8 \pm 0.9$ & -1.34 & $30.5 \pm 4.4$ \\
$\begin{array}{l}\text { Affinity } \\
\text { chromatography } \\
\text { only }\end{array}$ & $70.7 \pm 1.4$ & -1.28 & $27.6 \pm 3.0$ \\
Direct assay & - & -1.35 & $30.1 \pm 3.4$ \\
\hline
\end{tabular}

Each sample was assayed at 5 levels in duplicate, with individual recovery corrections, using rabbit 48 in the heterologous assay. The $50 \%$ inhibition point and slope of the inhibition curve was $5.2 \mathrm{pg} /$ tube and -1.2 respectively. All samples were parallel to the standard curve. was parallel to the standard curve, the slopes being -1.15 and -1.25 respectively. For testosterone 10 , 50,100 and $200 \mathrm{pg}$ was added to four $3 \mathrm{ml}$ aliquots of ovine plasma and the amount of testosterone recovered was $9.4 \pm 1.5 ; 49.8 \pm 2.5 ; \quad 102.5 \pm 8.9$; $216 \pm 8.4 \mathrm{pg}$ respectively. Testosterone was also assayed in $4 \mathrm{vol}(50 ; 100,250$ and $500 \mu \mathrm{l})$ of ram plasma following affinity chromatography extraction. The amount of testosterone measured was 3.5, 3.6, 3.5 and $3.5 \mathrm{ng} / \mathrm{ml}$ respectively. The sample was also paraliel to the standard curve, the slopes being -0.96 and -0.99 respectively. In both the oestradiol and testosterone assays the assays blanks were always undetectable.

\section{DISCUSSION}

The results described here support the previous conclusion $[5,6]$ that the use of an heterologous configuration at the site of attachment significantly reduces the recognition of the chemical bridge by the antibody. This was found using two antisera

Table 7. Extraction of oestradiol-17B from ovine serum using an affinity chromatography extraction procedure

\begin{tabular}{|c|c|c|}
\hline $\begin{array}{l}\text { Quantity of } \\
\text { oestradiol-17 } \\
\text { added (pg) }\end{array}$ & $\begin{array}{c}\text { Sample volume } \\
(\mu \mathrm{I})\end{array}$ & $\begin{array}{c}\text { Mean concentration of } \\
\text { oestradiol-17 } \beta \text { recovered } \\
(\mathrm{pg} \pm \mathrm{SEM})\end{array}$ \\
\hline $\begin{array}{r}10 \\
50 \\
100\end{array}$ & $\begin{array}{l}1000-3000 \\
250-900 \\
150-1000\end{array}$ & $\begin{array}{r}10.9 \pm 0.5 \\
49.5 \pm 1.1 \\
103.2 \pm 3.0\end{array}$ \\
\hline
\end{tabular}

Each sample was assayed in duplicate using 3 or 4 vol within the range shown. The concentration of oestradiol- $17 \beta$ in the control serum was $1.6 \pm 0.2 \mathrm{pg} / \mathrm{ml}$. 
(Table 1) raised against $17 \beta$-oestradiol-11 $\beta$-BSA. [9]. Furthermore, the slope of the inhibition curve was significantly steeper when using the heterologous compared to the homologous configuration of attachment, leading to increased assay sensitivity and precision $[5,6]$. However, if the site of attachment was too remote ( 3 and 6 positions), although two of the antisera could bind the label, the inhibition curves were not usable (Table 1).

The results described here also extend these findings and indicate that the occurrence of "bridge binding" may also be affected by the actual position of attachment to the steroid molecule. Although an homologous chemical bridge and site of attachment ( 3 position) were utilised in the testosterone assay a suitable slope, similar to the oestradiol-17 $\beta$ system, was achieved. Moreover, because similar results were obtained using antisera from two different animals this may be a common mechanism, rather than due to the individual characteristics of a single antiserum. This conclusion is supported by a previous investigation of a number of steroids [24], although exact titres and inhibition curves were not shown.

Why this phenomenon should apply to the 3 position of the steroid molecule and whether it is related to molecular folding and spatial relationships between hapten and carrier protein remains to be determined [6]. Interestingly, the extremely high titres of the testosterone antibodies (Tables 1 and 2), suggests a high affinity for the radiolabel. Previous results with androstenedione [7; unpublished data] indicated that very high antibody titres can be achieved when an homologous system is used. Normally however, the radiolabel is not easily displaced from the antibody.

The Scatchard analyses indicated the presence of a high affinity binding site in both the oestradiol-17 $\beta$ and testosterone antisera (Fig. 1, Table 2). However, two significantly different binding affinities were apparent (Fig. 1) in the testosterone assay when tested at high antibody concentrations. Two possible alternatives are either the presence of two pools of antibodies or an antibody with divalent characteristics [25], as described for monoclonal antibodies raised against deoxycorticosterone [26]. The Scatchard analysis and slope of the testosterone inhibition curves demonstrated that at the high antibody dilutions (Table 2) only the high affinity binding site was of importance.

The cross-reaction studies suggest that utilising the 11 position for oestradiol-17 $\beta$ can lead to specific antisera (Table 3) and is in agreement with the previous work of England et al.[9]. The testosterone assay also demonstrated good specificity (Table 3 ). There was some cross-reactivity with $5 \alpha$-dihydrotestosterone, but antibodies have been shown to have problems in differentiating between the 4-ene and $5 \alpha$ reduced forms of androgens [7, 27-30]. The specificity achieved in our assay system was better than that quoted by Cameron et al. [24], but this could be related to antibody concentration as this does have a significant effect on steroid antibody specificity [31]. Recently monoclonal antibody techniques have been used to produce a specific testosteronc antibody [32]. although monoclonal antibody affinities tend to be lower $[32,33]$.

Steroid antibody cross-reactivities are further highlighted by the specificity of the antibody-Sepharose (Table 4), where the antibody concentrations are high [31]. In agreement with the results of Glencross et al.[13] the oestradiol-17 $\beta$ antibody-Sepharose and also the testosterone antibody-Sepharose had low cross-reactivity with progesterone. Although Glencross et al.[13] reported no other cross-reactivities the results presented here (Table 4) demonstrate that steroids with a similar structure do cross-react significantly. However, this is not a problem when the extraction procedure is incorporated with a specific RIA. The elution profiles (Table 4) demonstrated that unbound steroid is removed by washing with water, while a wash with methanol is extremely efficient at removing the bound steroid. This technique is currently being investigated for the purification of radiolabelled steroid derivatives following iodination.

Unlike the previous report [13] the technique used here produced negligible assay blanks in either the testosterone or oestradiol assays. Comparison with other extraction systems and recovery estimates indicated that affinity chromatography is a reliable and repeatable technique and is therefore a suitable extraction procedure for steroids, as recently demonstrated for small molecular weight protein hormones [34]. The use of radioiodinated ligands in the radioimmunoassay, in conjunction with affinity chromatography, has a dual advantage of firstly, allowing individual recovery estimates on each sample and secondly, removes the need for extracting the standards [13]. Moreover, only one extraction step would suffice for samples being assayed for more than one hormone. Antibody-Sepharose for each of the hormones to be measured, could be pooled followed by specific RIA's for each of the hormones being measured.

In conclusion, we have demonstrated that by judicial selection of antibody and radioiodinated label very precise and sensitive assays can be obtained. In addition the incorporation of these assay systems with an affinity chromatography extraction procedure allows the measurement of low concentrations of steroids in large volumes of a range of biological fluids.

Acknowledgements-We thank, Miss J. Dawson, Mr J. Walia and Mr G. Andrews for excellent techical assistance; Mrs B. McKenzie for preparation of glassware; Mrs J. Cherrie for typing the manuscript and $\mathrm{Mr} \mathrm{C}$. Manson for art work; $\mathrm{Mr}$ B. Morris for the gift of ovine testosterone and ovine oestradiol antisera; Upjohn for the oestradiol $11 \alpha$ - and $11 \beta$-hemisuccinate and Scottish Antibody Production Unit for the second antibodies and normal serum. 


\section{REFERENCES}

1. Hunter W. M. and Corrie J. E. T.: Immunoassays for Clinical Chemistry: A Workshop Meeting. Churchill Livingstone, Edinburgh, Session 9, Chapters 1-7 (1982).

2. Scaramuzzi R. J., Lincoln D. W. and Weir B. J.: Reproductive endocrinology of domestic ruminants. $J$. Reprod Fert. Suppl. 30 (1981) pp. 1-263.

3. Schallenberger E., Walters D. L., Oschmann S. J. and Meyer H. H. D.: Endocrine changes during the early postpartum period in dairy cattle. 10th Intl. Congr. Anim. Reprod. and A.I., Univ. Illinois, U.S.A., Vol IV, Plenary Session III (1984) pp. 9-16.

4. Peters A. R. and Lamming G. E.: Endocrine changes in the post-partum period 10th Int. Cong. Anim. Reprod. and A.I., Univ. Illinois, U.S.A., Vol. IV, Plenary Session III (1984) pp. 17-24.

5. Corrie J. E. T. and Hunter W. M.: ${ }^{125}$ Iodinated tracers for hapten-specific radioimmunoassays. Meth. Enzym. 73 (1981) 79-112.

6. England B. G. and Nordblom G. D.: Chemistry and mechanisms of steroid immunogens. 10th Int. Cong. Anim. Reprod. and A.I., Univ. Illinois, U.S.A., Vol. IV, Plenary Session VIII (1984), pp. 1-6.

7. Nordblom G. D., Webb R., Counsell R. E. and England B. G.: A chemical approach to solving bridging phenomena in steroid radioimmunoassays. Steroids $\mathbf{3 8}$ (1981) 161-173.

8. Painter K. and Niswender G. D.: Radioiodinated steroid hormones-general principles. In Methods of Hormone Radioimmunoassay (Edited by B. Jaffe and II. R. Behrman). Academic Press, New York (1979) pp. 727-741.

9. England B. G., Niswender G. D. and Midgley A. R. Jr: Radioimmunoassay of estradiol-17 $\beta$ without chromatography. J. clin. Endocr. Metab. 38 (1974) 42-50.

10. Corrie J. E. T., Ratcliffe W. A. and Macpherson J. S.: The provision of ${ }^{125}$ I-labelled tracers for radioimmunoassay of haptens: a general approach? $\mathrm{J}$. Immun. Meth. 51 (1982) 159-166.

11. Glencross R. G., Munro I. B., Senior B. E. and Pope G. S.: Concentrations of oestradiol-17B, oestrone and progesterone in jugular venous plasma of cows during the oestrous cycle and in carly pregnancy. Acta endocr., Copenh. 73, (1973) 374-384.

12. Hauger R. L., Karsch F. J. and Foster D. L.: A new concept for control of the estrous cycle of the ewe based on the temporal relationships between luteinizing hormone, estradiol and progesterone in peripheral serum and evidence that progesterone inhibits tonic $\mathrm{LH}$ secretion. Endocrinology 101 (1977) 807-817.

13. Glencross R. G., Abeywardere S. A., Corney S. J. and Morris H. S.: The use of oestradiol-17 $\beta$ antiserum covalently coupled to Sepharose to extract oestradiol$17 \beta$ from biological fluids. J. Chromat. Biomed. Applic. 223 (1981) 193-197.

14. Hunter W. M., Nars P. W. and Rutherford F. J.: Preparation and behaviour of ${ }^{125}$ I-labelled radioligands for phenolic and neutral steroids. In Steroid Immunoassay (Edited by E. H. D. Cameron, S. G. Hillier and K. Griffiths). Alpha Omega, Cardiff (1975) pp. 141-152.

15. Diekman M. A., O'Callaghan P., Nett T. M. and Niswender G. D.: Validation of methods and quantification of luteal receptors for LH throughout the estrous cycle and early pregnancy in ewes. Biol. Reprod. 19 (1978) 999-1009.

16. Land R. B., Morris B. A., Baxter G., Fordyce M. and Forster J.: Improvement of sheep fecundity by treatment with antisera to gonadal steroids. $J$. reprod. Fert. 66 (1982) 625-634.
17. Abraham G. E.: Solid phase radioimmunoassay of estradiol-17ß. J. clin. Endocr. Metab. 29 (1969) 866-870.

18. Niswender G. D. and Midgley A. R. Jr: Haptenradioimmunoassay for steroid hormones. In Immunologic Methods in Steroid Determination (Edited by F. G. Peron and B. V. Caldwell) Appleton-CenturyCrofts, New York (1970) pp. 149-173.

19. Rodbard D. and Lewald J. G.: Computer analysis of radioligand assay and radioimmunoassay data. Acta endocr., Copenh. Suppl. 147 (1970) 79-103.

20. Scatchard G.: The attraction of proteins for small molecules and ions. Ann. N.Y. Acad. Sci. 51 (1949) 660-672.

21. Chamness G. C. and McGuire W. L.: Scatchard plots: common errors in correction and interpretation. Steroids 26 (1975) 538-542.

22. Rosenthal H. E.: A graphic method for the determination and presentation of binding parameters in a complex system. Analyt. Biochem. 20 (1967) 525-532.

23. England B. G., Dahmer M. K. and Webb R.: Relationships between follicular size and antral fluid steroid concentrations at three stages of the estrous cycle in the ewe. Biol. Reprod. 24 (1981) 1068-1075.

24. Cameron E. H. D., Scarisbrick J. J., Morris S. E., Hillier S. G. and Read G.: Some aspects of the use of ${ }^{125}$ I-labelled ligands for steroid radioimmunoassay. $J$. steroid Biochem. 5 (1974) 749-756.

25. Steward M. W.: Affinity of the antibody-antigen reaction and its biological significance. In Immunochemistry (Edited by L. E. Glynn and M. W. Steward). Wiley, New York (1977) pp. 233-262.

26. Al-Dujaili E. A. S., Hubbard A. L., van Heyningen V. and Edwards C. R. W.: Production of high affinity monoclonal antibodies to deoxycorticosterone. $J$. steroid Biochem. 20 (1984) 849-852.

27. Bermúdez J. A., Coronado V., Mijares A., León C., Velázquez A., Nobel P. and Mateos J. L.: Stereochemical approach to increase the specificity of steroid antibodies. J. steroid Biochem. 6 (1975) 283-290.

28. Milewich L., Gomez-Sanchez C., Macdonald P. C. and Siiteri P. K.: Radioimmunoassay of androstenedione: the steroid molecule as a probe for antibody specificity. J. steroid Biochem. 6 (1975) 1381-1387.

29. Parker L. N., Grover P. K. and Odell W. D.: An improved radioimmunoassay for 4-androstene-3,17dione. Steroids 29 (1977) 715-724.

30. Rao P. N., Moore P. H., Jr. Peterson D. M. and Tcholakian R. K.: Synthesis of new steroid haptens for radioimmunoassay-part V. 19- $O$ carboxymethyl ether derivative of testosterone. A highly specific antiserum for immunoassay of testosterone from both male and female plasma without chromatography. $J$. steroid Biochem. 9 (1978) 539-545

31. Webb R., Land R. B., Pathiraja N. and Morris B. A.: Passive immunization against steroid hormones in the female. In Immunological Aspects of Reproduction (Edited by D. B. Crighton). Butterworths, London (1984) pp. $475-499$.

32. Kohen F., Lichter S., Eshhar Z. and Lindner H. R.: Preparation of monoclonal antibodies able to discriminate between testosterone and $5 \alpha$-dihydrotestosterone. Steroids 39 (1982) 453-459.

33. Forth V. E. and Wang D. Y.: Characteristics of monoclonal antibodies raised against testosterone. J. steroid Biochem. 19 (1983) 1605-1610.

34. Kikuchi K., Tanaka M., Abe K., Yamaguchi K., Kimura $S$. and Adachi I.: Rapid and Specific radioimmunoassays for $\beta$-endorphin and $\beta$-lipotropin in affinity-purified human plasma. J. clin. Endocr. Metab. 59 (1984) 287-292. 